\title{
The potential utilization of slag generated from iron- and steelmaking industries: a review
}

\author{
Xiaolei Zhang $\cdot$ Jiaxin Chen $\cdot$ JingJing Jiang $\cdot$ Ji Li $\cdot$ R. D. Tyagi \\ Rao Y. Surampalli
}

Received: 5 May 2019/Accepted: 6 September 2019

(C) Springer Nature B.V. 2019

\begin{abstract}
Along with iron and steel production, large amount of slag is generated. Proper management on the iron- and steelmaking slag is highly demanded due to the high cost of direct disposal of the slag to landfill, which is the most adopted management approach. In this article, the potential application of iron- and steelmaking slag has been reviewed, which included the slag utilization in construction as cement and sand, in water, soil, and gas treatment, as well as in value material recovery. In addition, the challenge and required effort to be made in iron- and steelmaking slag management have been discussed.
\end{abstract}

X. Zhang · J. Jiang $\cdot$ J. Li $(\bowtie)$

Department of Civil and Environmental Engineering, Harbin Institute of Technology (Shenzhen),

Shenzhen 518055, Guangdong, People's Republic of China

e-mail: jili99@foxmail.com

J. Chen

Department of Civil and Environmental Engineering, Shantou University, Shantou 515063, Guangdong, People's Republic of China

R. D. Tyagi

INRS Eau, Terre et Environnement, 490, rue de la

Couronne, Québec G1K 9A9, Canada

\section{R. Y. Surampalli}

Department of Civil Engineering, University of NebraskaLincoln, N104 SEC, PO Box 886105, Lincoln,

NE 68588-6105, USA
Keywords Construction - Environmental treatment . Valuable substance recovery

\section{Introduction}

Slag is the by-product of iron- and steelmaking processes. Normally, around half to one tonne of slag would be generated for yielding one tonne of rolled iron or steel (Lobato et al. 2015). It was reported that the world steel production was 1.9 billion tonnes in 2016, which suggested that at least around 1 billion tonnes of slag is produced during the year (Worldsteel Association 2016). The large amount production of slag requires appropriate management. Landfill is the simplest and most commonly adopted disposal strategy of slag management; however, the cost gradually increases as the land space and the environment regulations become tense and strict, respectively. Alternative management solutions are highly required. Currently, the idea of waste management is toward to converting waste to valuable products, but it should avoid the toxic elements or other potential contaminants to accumulate in the application chain. In fact, waste generated in one field could be useful materials in other areas. For instance, wastewater sludge is the waste generated in wastewater treatment, but it is considered as fertilizer in agriculture due to the presence of the essential element (nitrogen, phosphorus, potassium) for plant growth. Similarly, under 
circular economy concept slag as waste of iron- and steelmaking industries can be used as raw materials of other value product production (Velenturf et al. 2019; Wang et al. 2018).

Iron- and steelmaking slag has been widely studied for manufacturing construction materials, such as asphaltic concrete aggregate, road base, railroad ballasts, and roofing granules after grinding (Biskri et al. 2017; Ferreira et al. 2016; Pasetto et al. 2017; Vijayaraghavan et al. 2017); as fertilizer or soil conditioner after grinding (Ali and Shahram 2007; Li and Dai 2018; Wang and Cai 2006); as adsorbents for heavy metal and phosphorus removal from wastewater after activating process (Kim et al. 2008; Wu et al. 2014; Zhang and Itoh 2006); for neutralizing acid mine drainage (Goetz and Riefler 2014; Moodley et al. 2017); and for carbon dioxide fixation (Pan et al. 2016). In addition, the slag could be also used as iron source (also called iron recycle) due to the fact that the slag contains iron in abundance (around 20\% iron content) (Lan et al. 2017). Generally, the slag with rich iron content could be directly returned to the furnace as feedstock. However, in order to increase the iron content in the slag, pre-treatment is usually performed prior to return the slag to the furnace as feedstock. The pretreatments mostly used are leaching and thermal treatment for removing the impurities (mainly toxic metals) and increasing the iron content (Baciocchi et al. 2015; Gomes and Pinto 2006; Peters and Colo 1978). The released toxic metals would be treated for recovery or removal through adsorption, extraction, or precipitation (Battsengel et al. 2018; Genç-Fuhrman et al. 2007). Iron- and steelmaking slag management can be fulfilled by processing or converting slag to the materials which can be used in construction or environmental treatments, or recovering value products.

Piatak et al. have reviewed the characteristic and environmental impact of ferrous and non-ferrous slag, and revealed that compared to non-ferrous slag, ferrous slag is more environmentally friendly and thus exhibited a greater potential for reuse or valuable material recovery (Piatak et al. 2015). Recently, Li and Dai have reviewed to converting the ferrous slag to glass-ceramics, mineral wool, and fertilizers ( $\mathrm{Li}$ and Dai 2018). In fact, iron- and steel- making slag has been widely investigated for producing construction materials, and applying in environmental treatment; however, the related studies have not been discussed.
This article has reviewed the utilization of slag in construction and environmental treatment. In addition, recovery of valuable substances from the slag is also demonstrated. The problems that the application of iron- and steelmaking slag in construction and environmental treatment is facing have been discussed. The article was aimed to provide an insight of proper management on iron- and steelmaking slag.

\section{Iron- and steelmaking slag}

Slag is an inevitable by-product in metal making process. Iron slag (slag of blast furnace BF) and steel slag (slag of basic oxygen furnace BOF, and electric arc furnace, EAF) are two types of slag generated during iron and steel production processes. The composition of the slag varies with the production processes and the composition of the feed materials (ore). Detailed chemical composition and mineralogical characteristics have been discussed by Piatak et al. (2015) and Kambole et al. (2017). The major elements in the slag are iron (for BF), calcium, magnesium, silica, and aluminum, as well as trace amount of heavy metals, $\mathrm{Cr}, \mathrm{Ni}, \mathrm{Pb}, \mathrm{Zn}$, etc. These elements are mostly present in the forms of their oxides. The compositions of the slag are summarized in Table 1.

According to the difference of the methods used for cooling the molten slag, slag is divided into air-cooled blast furnace slag (ACBF), air, water, or steam cooled blast furnace slag (expanded or foamed blast furnace slag), air- and water-cooled blast furnace slag (pelletized blast furnace slag) and water-cooled blast furnace slag (granulated blast furnace slag). The slag is in bulk formation after formed, and thus, it will be grinded before any further utilization.

\section{Application of iron- and steelmaking slag}

Application in construction

The large volume production of slag from iron- and steelmaking process and the tightened regulation on the slag disposal urge engineers and researchers to explore the way which can massively use the slag. As the development of global economy, the need on buildings and roads extensively increases. Iron- and steelmaking slag contains large fraction of lime and 
Table 1 Composition of iron slag and steel slag

\begin{tabular}{|c|c|c|c|}
\hline Composition & $\begin{array}{l}\text { Iron slag }(\mathrm{BF}) \\
(\% \mathrm{w} / \mathrm{w})\end{array}$ & $\begin{array}{l}\text { Steel slag (BOF, } \\
\text { EAF) }(\% \text { w/w })\end{array}$ & Refs. \\
\hline Calcium $(\mathrm{CaO})$ & $30-50$ & $30-60$ & \multirow{6}{*}{$\begin{array}{l}\text { Basu et al. (2008), Danilov (2003), Emery } \\
\text { (1992), Kalyoncu (2000), Mihok et al. } \\
\text { (2006), Piatak et al. (2015), Reddy et al. } \\
\text { (2006) }\end{array}$} \\
\hline Silica $\left(\mathrm{SiO}_{2}\right)$ & $25-45$ & $10-45$ & \\
\hline Aluminum $\left(\mathrm{Al}_{2} \mathrm{O}_{3}\right)$ & $0-10$ & $0-15$ & \\
\hline Magnesium (MgO) & $3.5-15$ & $5-20$ & \\
\hline Iron $\left(\mathrm{FeO}\right.$ and $\left.\mathrm{Fe}_{2} \mathrm{O}_{3}\right)$ & $10-30$ & $0.1-3.6$ & \\
\hline Others $(\mathrm{P}, \mathrm{S}$, toxic metals) & $<5 \%$ & $<5 \%$ & \\
\hline
\end{tabular}

silica, which are the main components in most of construction materials. Therefore, slag has been employed as construction resource for mitigating the pressure from expensive disposal and reducing the construction cost (Heribeert and Kuehn 2004; Hiroyuki et al. 2005). The slag has been investigated to be directly used as granular base, embankments or fill, highway shoulders, and asphalt pavement after crush and screen (Chen et al. 2017; Li et al. 2016; Wang 2016; Yildirim and Prezzi 2017). However, usually, the slag would be stored for a certain time for gaining the saturation of moisture prior to using in order to avoid the swelling of the slag in construction (caused by lime) (Jukes 2003). Apart from the applications in road constructing, slag has also been studied to produce cement and sand (Carvalho et al. 2017; Li et al. 2018; Ouda and Abdel-Gawwad 2017). The details information is presented below:

\section{Cement}

Cement produced from slag has been used for decades, and the most typical one is Portland clinker (35\%)Steelmaking Slag (30\%)-Blast Furnace Slag (30\%) Cement (PSSBFC) (Sun and Yuan 1983; Wang and Lin 1983). Iron- and steelmaking slag has been studied to be used for blended cement making or as a raw material in cement clinker. There are several parameters such as slag composition and the formation of the oxides, considered to affect the feasibility of slag to produce cement. Among all, the similarity of composition between slag and commercial cement [Portland Cement (PC)] determines if the slag could be used for manufacture cement. The fractions of free lime $(\mathrm{CaO})$ and free magnesia $(\mathrm{MgO})$ in slag are essential factors in cement production from slag as they significantly affect the hydraulic properties of cement which is associated with volume stability of the products. Free lime and free magnesia can react with water and hence induce large volume expansions of the slag. It would thus cause the premature failure when the slag is employed in roads. Usually, free lime is less than $20 \%$ $\mathrm{w} / \mathrm{w}$ (based on slag weight) and free magnesia is less than 3\% in the slag (Kambole et al. 2017). It suggests that the content of free lime and free magnesia should be lower than $7 \%$ and $4 \%$, respectively, when the slag was used in unbound and bitumen bound layers, respectively (Geiseler 1996). Attention should be paid on the free lime content when utilizing the iron- and steelmaking slag in road construction as free magnesia is normally less than $3 \%$ in the slag.

Iron content including $\mathrm{FeO}, \mathrm{Fe}^{0}$, and $\mathrm{Fe}_{2} \mathrm{O}_{3}$ is another important factor to evaluate the possibility of slag as cement due to the concerns on the volume stability and appearance.

Generally, the production of cement from slag can be simply processed as grinding, treating, and blending. The order of the procedure is varied based on the treatment methods. Thermal and magnetic treatments are mostly applied technologies (Alanyali et al. 2009; Heikal et al. 2015; Reddy et al. 2006). Thermal treatment is to first melt the slag, and then, let it cool down in different cooling temperature for converting the free metallic oxides, especially $\mathrm{CaO}$, into complex with other substances such as $\mathrm{SiO}_{2}$ and $\mathrm{Al}_{2} \mathrm{O}_{3}$, and thus enhance the volume stability of the slag. The thermal treated slag will be grinded and screened for size selection after cooling. If necessary, PC clinker will be added to modify the property of the slag. Magnetic treatment is mainly used for cement production from the slag which has similar component with commercial cement but high content of iron. Magnetic separation of iron is performed after grinding and screen. The slag obtained from separation 
process could be used as cement with or without the addition of PC clinker based on the practical condition.

Recently, it was reported that slag after being activated with sodium carbonate could be used in autoclaved aerated concrete instead of cement (Ke et al. 2016; Yuan et al. 2017). The autoclaved aerated concrete produced from the alkali-activated slag showed comparable strength, raw density, thermal conductivity, porosity, and drying shrinkage as the one prepared from cement (Yuan et al. 2017). It suggests that the slag can replace the cement to produce autoclaved aerated concrete without effecting on the property of the product. In addition, it was observed that the method could greatly reduce the cost, energy consumption, and greenhouse gas emission. Similar results have been also achieved by others (Balczár et al. 2017; Burciaga-Díaz and Escalante-García 2017).

\section{Sand}

Sand is another mostly used material in construction. Over last decades, iron- and steelmaking slag has been used in concrete as sand (Dieter et al. 1988). Researchers have produced sand-like product from BF slag and achieved encourage results (Senani et al. 2016; Takahashi and Yabuta 2002). To produce sand from slag, rapidly cooling on the molten BF slag from blast furnace (temperature is around $1500{ }^{\circ} \mathrm{C}$ ) with pressured water can be performed, and then crushed and screened the slag to obtain a similar particle size with commercial sand. Thereafter, inhibitors were normally added to prevent the consolidation of the slag. The sand-like product, commercially called granulated BF slag sand or Sandy-S, has widely used as fine concrete aggregate and showed compatible result (Ouda and Abdel-Gawwad 2017; Turhan 2006). Studies have revealed that utilization of sand produced from iron- and steelmaking slag performed similarly as the commercial sand in the cement mortar and foundry industries (Le et al. 2017; Li et al. 2018; Murthy and Rao 2016; Ouda and Abdel-Gawwad 2017).

Overall, the use of iron- and steelmaking slag in construction has significantly reduced the tension for the slag dumping and disposal due to the fact that construction is capable of consuming the slag in large amount. In addition, the performance of slag in construction is rather encouraging. However, there is still consideration on long-term volume stability of the slag in construction and the risk to environment and human health (Ferreira et al. 2016; Reis da Silva et al. 2007). Work on improving the volume stability of iron- and steelmaking slag is greatly required in order to promote the application of slag-obtained sand in construction.

Application in environmental treatments

The large amount production of iron- and steelmaking slag has proposed a great challenge to the environment as it has been considered as pollutant. In fact, the slag has showed impressive performance on removing contaminants from air, water, and soil (Barca et al. 2014, 2018; Jo et al. 2015; Yu et al. 2015; Zhou et al. 2016; Zuo et al. 2015). It indicates that the iron- and steelmaking slag has great potential in the application of environment treatment practice. The detailed information has been discussed below:

\section{Water treatment}

As adsorbent and filtration media Heavy metal removal from wastewater has grabbed a growing attention due to their toxicity to the living beings. Adsorption is the most applied method for heavy metal removal. Among all the commonly used adsorbents (various zeolite, fly ash, clay, and zero-valent irons, activated carbon), activated carbon is considered as the best performed one (Da'na and Awad 2017; Karnib et al. 2014; Pap et al. 2017). However, the high cost of heavy metal removal by activated carbon has hindered its application, and thus, seeking on costeffective adsorbent is highly needed. Researchers have pointed out that iron- and steelmaking slag was a suitable alternative (Xue et al. 2009; Zahar et al. 2015). As shown in Table 1, iron- and steelmaking slag mainly contains calcium oxide, magnesium oxide, and aluminum silicates, which have great affinity to heavy metals (Curkovii et al. 2000).

The mechanism of heavy metal removal with slag is considered to be the adsorption, precipitation, and ion exchange (Dimitrova 1996, 2002; Kim et al. 2008). Slag hydrolysis converts the oxides into their relative hydroxides; for example, $\mathrm{CaO}$ could be turned into the form of $\mathrm{Ca}(\mathrm{OH})_{2}$ which has higher solubility than most of heavy metal hydroxides, in the presence of 
water. Thus, when heavy metal exposes into the system, $\mathrm{Ca}$ in slag will be exchanged by heavy metal which results in precipitation of heavy metal onto slag or in the solution (Dimitrova 2002). In addition, the reaction occurring between soluble compounds in slag and heavy metals in solution to form hydro-oxo complexes would cause heavy metal removal as well (Beh et al. 2010; Dimitrova 1996; Kim et al. 2008). The study on the heavy metal removal with the slag before 2011 has been extensively reviewed by other researchers (Ahmaruzzaman 2011; Hashim et al. 2011); thus, in this article the related work after 2011 is summarized in Table 2. In fact, interests in evaluating the heave metal removal with iron- and steelmaking slag have reduced in recently years. As shown that there were toxic metals in the slag (Table 1), it suggests that the metals might be released during heavy metal removal from water and hence brings new contaminants to the water. It would be the cause of the less attention on the heave metal removal with iron- and steelmaking slag.

Filtration is a combination of physical (size exclusion and attachment) and chemical (sorption) processes in water treatment. Studies using iron- and steelmaking slag as filtration media have shown that the slag had good performance in various types of wastewater treatment and revealed that the slag was capable of removing contaminants such as suspended solids, chemical oxygen demand (COD), biochemical oxygen demand (BOD), phosphate (P), and ammo-

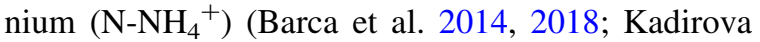
et al. 2015; Zhou et al. 2016; Zuo et al. 2015). It was predicted that the porous structure of the slag would absorb the contaminants and free lime in the slag could react with the contaminants (Jha et al. 2004, 2008; Lu et al. 2008). In addition, inertial impaction, diffusion, interception, size exclusion, and electrostatic interaction could also be the reason for contaminant removal in slag filtration (Gao et al. 2017; Zhou et al. 2016). It was reported that ironmaking slag was capable of removal of hydrogen sulfide which was attributed to the oxidation and acid-base reaction (Xie et al. 2017). The hydrogen sulfide was converted to acid volatile sulfide (AVS), elemental sulfur, and thiosulfate after being reacted with the slag.

Among all the contaminants, phosphorus removal with iron- and steelmaking slag was studied the most (Table 3). It would be due to the high affinity of the slag component such as free lime to the phosphorus, as well as that phosphorus in the wastewater normally was difficult to eliminate with biological treatment process which was normally used to remove COD, $\mathrm{BOD}$, and nitrogen.

Neutralizing agent Iron- and steelmaking slag contains abundant basic materials such as $\mathrm{CaO}$ and $\mathrm{MgO}$ (Table 1). Therefore, the slag would replace the commercial neutralizing agents such as lime, limestone, and calcined magnesia. Various slags have been demonstrated to neutralize $\mathrm{pH}$ of solutions (Gahan et al. 2009; Yilmaz et al. 2010). Composition of slag, formation of the oxides in slag, and physical characters of slag (particle size and shape) could significantly impact on neutralization. It was reported that the neutralizing capacity of the slag was affected by the form of oxides $\left(\mathrm{CaO}, \mathrm{MgO}, \mathrm{SiO}_{2}\right)$ and particle

Table 2 Heavy metal removal using iron- and steelmaking slag

\begin{tabular}{llll}
\hline Slag & Heavy metal & The highest removal efficiency (\%) & Refs. \\
\hline Steelmaking slag & As (III), As (V) & $95-100$ & Oh et al. (2012) \\
Ironmaking slag & $\mathrm{Zn}(\mathrm{II})$ & 85 & Cantarino et al. (2012) \\
Ironmaking slag & $\mathrm{Cu}(\mathrm{II})$ & 99.9 & Santos et al. (2013) \\
Steelmaking slag & $\mathrm{Cd}(\mathrm{II})$ & 99.1 & Duan and Su (2014) \\
Steelmaking slag & $\mathrm{Pb}(\mathrm{II})$ & 99.2 & Wu et al. (2014) \\
Steelmaking slag & $\mathrm{As}(\mathrm{III})$, As(V) & 93.7 & Mercado-Borrayo et al. (2014) \\
Ironmaking slag & $\mathrm{Cs}(\mathrm{I}), \mathrm{Sr}(\mathrm{II})$ & $57.4,53.6$ & Tsutsumi et al. (2014) \\
Steelmaking slag (modified) & $\mathrm{Ni}(\mathrm{II})$ & - & Kadirova et al. (2015) \\
Steelmaking slag & $\mathrm{Mn}(\mathrm{II})$ & 95 & Zahar et al. (2015) \\
Steelmaking slag & $\mathrm{Ni}(\mathrm{II})$ & - & Sarkar et al. (2017) \\
\hline
\end{tabular}


Table 3 Contaminants removal with iron- and steelmaking slag

\begin{tabular}{|c|c|c|c|}
\hline Slag type & Removed contaminants & Removal efficiency (\%) & References \\
\hline \multirow[t]{2}{*}{ Steelmaking slag (modified) } & Phosphorus & 49.2 & Jha et al. (2008) \\
\hline & Ammonia & 7.2 & \\
\hline Steelmaking slag (modified) & Phosphorus & 85.2 & Barca et al. (2012) \\
\hline Steelmaking slag (modified) & Phosphorus & 80.0 & Li et al. (2013) \\
\hline \multirow[t]{4}{*}{ Steelmaking slag } & Phosphorus & 99.9 & Claveau-Mallet et al. (2013) \\
\hline & Fluoride & 85.3 & \\
\hline & $\mathrm{Mn}(\mathrm{II})$ & 98.0 & \\
\hline & $\mathrm{Zn}$ (II) & 99.3 & \\
\hline Slag & Phosphorus & 99.6 & Barca et al. (2014) \\
\hline Steelmaking slag & $\mathrm{H}_{2} \mathrm{~S}$ & 93.5 & Okada et al. (2014) \\
\hline Steelmaking slag & COD & $84.0-92.0$ & Jo et al. (2015) \\
\hline Ironmaking slag & Phosphorus & 96.3 & Han et al. (2015) \\
\hline Steelmaking slag (modified) & Phosphorus & 99.9 & Yu et al. (2015) \\
\hline Ironmaking slag & Phosphorus & 95.8 & Han et al. (2016) \\
\hline Ironmaking slag & Phosphorus & $>90$ & Zhou et al. (2016) \\
\hline Steelmaking slag (modified) & Phosphorus & $>60$ & Park et al. (2017) \\
\hline Steelmaking slag (modified) & Phosphorus & 88 & Claveau-Mallet et al. (2017) \\
\hline Steelmaking slag & $\mathrm{H}_{2} \mathrm{~S}$ & 94 & Xie et al. (2017) \\
\hline Steelmaking slag & Phosphorus & 96 & Barca et al. (2018) \\
\hline
\end{tabular}

size of the slag (Bodurtha and Brassard 2000). The results displayed that the slag with higher free oxides content and smaller particle size would more rapidly bring liquors from low $\mathrm{pH}$ to high $\mathrm{pH}$ in comparison with the slag with more bound oxides and lager particle size. The typical application of iron- and steelmaking slag in neutralization is the amendment of acid mine drainage (AMD) which is characterized with low $\mathrm{pH}(2.5-5.0)$ and high concentration of $\mathrm{Fe}^{2+}$ and $\mathrm{Fe}^{3+}$ (Goetz and Riefler 2014; Moodley et al. 2017). Raising $\mathrm{pH}$ and removing iron are the aim in AMD amendment. It was found that iron- and steelmaking slag could effectively generate alkalinity in AMD and precipitate iron (Goetz and Riefler 2014; Masindi et al. 2017, 2018). It suggests that iron- and steelmaking slag could be promising material to treat acid mine drainage.

\section{Soil treatment}

Similar as amendment of acidic liquors, iron- and steelmaking slag has also been used to amend acidic soil. Study has reported that the addition of converter slag (a type of steelmaking slag) could increase $\mathrm{pH}$ of acidic soils and the concentration of the available iron,
$\mathrm{P}$, and $\mathrm{Mn}$ in soil for plants (rice, maize, and tea) growth (Ali and Shahram 2007). It indicates that the addition of slag in soil also affects other properties of soil apart from acidity of soil. Negim et al. (2010) studied the effect of steelmaking slag on soil for bean growth (Negim et al. 2010). They found that the soil conditioned by slag enhanced bean growth with compared to plain soil. Moreover, as mentioned, ironand steelmaking slag contains abundant $\mathrm{Ca}, \mathrm{Mg}$, and $\mathrm{Fe}$, which are important elements in plant growth. It suggests that the slag could amend the soil which has elements $\mathrm{Ca}, \mathrm{Mg}$, and $\mathrm{Fe}$ in shortage. Researchers added steelmaking slag to Fe-deficient calcareous soils and planted corn with the modified soil and found that available $\mathrm{Fe}$ for plant growth was increased in soil (Wang and Cai 2006). The slag application in soil is a promising way to amend soil properties in the area where soil is not suitable for farming, which can be also considered slag as fertilizer (Li and Dai 2018; Qiu et al. 2012).

\section{Gas treatment}

$\mathrm{CO}_{2}$ absorbents Global warming which is predicated to be caused due to the greenhouse gas 
emission has become a serious environmental problem. The technology of carbon dioxide capture and storage, also called $\mathrm{CO}_{2}$ sequestration, has been paid a great attention recently. Mineral sequestration which fixes carbon dioxide by forming carbonates is one of most potential methods in carbon sequestration (Huijgen and Comans 2003; Santos et al. 2013). Ironand steelmaking slag richly containing $\mathrm{CO}_{2}$ absorbents such as $\mathrm{CaO}$ and $\mathrm{MgO}$ would be a great candidate for $\mathrm{CO}_{2}$ mineral sequestration. Direct (Eq. 1) and indirect (Eq. 2) carbonation have been reported using for carbon dioxide capture and storage. The direct route injects $\mathrm{CO}_{2}$ into dry slag to accomplish carbonation, while the indirect route uses $\mathrm{Ca}$ and $\mathrm{Mg}$ ions leached out from the slag to precipitate $\mathrm{CO}_{2}$ to complete carbonation (Bao et al. 2010; Sun et al. 2011).

$$
\begin{aligned}
& \mathrm{CaO} / \mathrm{MgO}+\mathrm{CO}_{2} \rightarrow \mathrm{CaCO}_{3} / \mathrm{MgCO}_{3} \\
& \mathrm{Ca}^{2+} / \mathrm{Mg}^{2+}+\mathrm{CO}_{2}+\mathrm{H}_{2} \mathrm{O} \\
& \stackrel{\mathrm{CaCO}}{3} / \mathrm{MgCO}_{3}+2 \mathrm{H}^{+}
\end{aligned}
$$

According to the reports, steelmaking slag exhibited great potential in carbon sequestration (El-Naas et al. 2015; Gopinath and Mehra 2016; Pan et al. 2016). Study showed that the factors including the particle size of the grinded slag, surface area, and calcium leaching rate have significantly impacted on carbon dioxide sequestration (Ghouleh et al. 2017; Rawlins 2008). It was observed that small particlesized slag was more efficient in sequestration process than the big-sized slag, and the slag with high calcium leaching rate was more cost-effective than the slag with low calcium leaching rate. It was due to that small-size slag provides larger surface area than big size ones when the equal amount slag was utilized. Calcium in the slag is the function material to capture $\mathrm{CO}_{2}$; hence, high calcium leaching rate would promote $\mathrm{CO}_{2}$ sequestration. It suggests that the process would be cost-effective than the slag with low calcium leaching rate.

The use of iron- and steelmaking slag in carbon sequestration might be another way to consume the slag in large quantity besides the use of slag in construction. In addition, as mentioned, the large content of free lime in the iron- and steelmaking slag was the barrier of slag utilization in construction; the volume stability of the slag would be highly improved after being employed in the carbon sequestration.
Hence, the slag gone through carbon storage would be great material using in construction. However, there is still need for evaluating the cost balance using for grinding slag and storing carbon dioxide due to the slow reaction kinetics of the carbonation. It reveals that the reaction kinetics could be enhanced by adjusting $\mathrm{CO}_{2}$ pressure, temperature, and water-tosolid ratio (Ukwattage et al. 2017). However, the improvement was limited. Further study is essentially required.

Catalysts $\mathrm{CH}_{4}$ is another contributor in greenhouse effect. Dry reforming of $\mathrm{CH}_{4}$ is effective method to reduce greenhouse gas emission and produce green fuel $\left(\mathrm{H}_{2}\right)$. Generally, metal catalysts such as $\mathrm{Ni} / \mathrm{La} /$ $\mathrm{Al}_{2} \mathrm{O}_{3}$ and $\mathrm{Ni} / \gamma-\mathrm{Al}_{2} \mathrm{O}_{3}$ were applied to catalyze the reforming process (Aramouni et al. 2018); however, the high cost has hampered the technology of $\mathrm{CH}_{4}$ reforming with $\mathrm{CO}_{2}$. Iron- and steelmaking slag with iron in abundance has been used as catalyst in reforming of methane to generate syngas (Eq. 3) (Fidalgo et al. 2009). The result revealed that the conversion using slag mixing with activated carbon had higher stability than using solo activated carbon. It implies that the slag is capable of catalyzing $\mathrm{CH}_{4}$ reforming.

$\mathrm{CH}_{4}+\mathrm{CO}_{2} \stackrel{\text { Temperature/catalyst }}{\longrightarrow} 2 \mathrm{CO}+2 \mathrm{H}_{2}$

In short, iron- and steelmaking slag has shown great potential in environmental treatment. It is a cheap and relatively effective resource in water treatment, soil amendment, and greenhouse emission control; however, the application of the slag in environment field is still in its enfant stage; further efforts are needed to be made.

\section{Recovery of valuable substance from iron- and steelmaking slag}

Iron and lime

The slag generated from iron- and steelmaking industry is characterized with high content of lime, magnesia, silicates, and iron (Table 1). Iron and lime are two essential substances in iron- and steelmaking process as iron is the raw material of iron- and steelmaking and lime is added for slag formation 
(Kalyoncu 2000). High cost required in transporting the slag from iron- and steelmaking industries to the sites of construction and environmental treatment has hindered the application. Recycling iron and lime from the slag and adding them back to iron- and steelmaking process would reduce the cost for making iron and steel, and the cost for transporting slag for disposal or other utilization. Among all the slag, blast furnace (BF) slag and steel slag have more value in iron recycle due to their attractive iron content (Shen and Forssberg 2003). A German company called STEIN Injection Technology developed a method to achieve iron and lime recycling (Danilov 2003). The process included slag cooling, primary screening, iron separating, and secondary screening. The cooling was accomplished in hoppers. Primary screening was a preparation of scalp metal separation. Magnetic separators were employed to recovery iron from the slag, and the iron obtained from separation was sent back to production line as iron raw material. The nonmagnetic portion of the slag (mainly containing lime) was further grinded to relative size according to requirements. The recycled lime was used in iron- and steelmaking process after mixing with a certain amount of fresh lime. (The addition of fresh lime was determined by the steelmaking regime.)

Chemical leaching is another effective approach using for iron recycling from iron- and steelmaking slag (Gomes and Pinto 2006). Usually, control on $\mathrm{pH}$ in the leaching process can manipulate the sequence of elements leaching out from the slag due to the difference of the solubility of each component in slag under different $\mathrm{pH}$ (Bao et al. 2010; Xiang et al. 2018). It was reported that $\mathrm{Ca}, \mathrm{Mg}$, and toxic metals in slag such as $\mathrm{Cr}, \mathrm{Ni}, \mathrm{Pb}$, and $\mathrm{Zn}$, could be leached out by adjusting $\mathrm{pH}$, and the residue was highly concentrated iron complex (Apul et al. 2005). It reveals that leaching could be used for iron recycling.

Valuable metals

Apart from iron, calcium, and magnesium, heavy metals such as chromium, lead, manganese, and zinc are also present in large amounts in certain slags such as electric arc furnace slag (Coppola et al. 2016; Santamaría et al. 2017). These heavy metals are mainly from the addition of these heavy metals during iron and steel production for improving the property of the products and the presence of these metals in ore
(He et al. 2017; Hocheng et al. 2014). The metals are required to be separated from the slag before the slag disposal due to their toxicity. Moreover, the high value of these metals in industry also encourages researchers to study the separation of these metals from the slag. Therefore, recovery of these metals becomes rather promising. Various technologies such as flotation, leaching, precipitation, and heating have been developed for metal recovery from different types of slag (Lenz and Martins 2007; Shen and Forssberg 2003; Spooren et al. 2016). Generally, the process using for recovering metals from the slag is combination of these technologies.

Among all the methods employed for metal recovery, leaching is the most widely used one as it can be a standalone process as well as a pre-treatment of slag application in construction and environmental treatment. Decades ago, a method for zinc recovery from steelmaking slag through ammonia and carbon dioxide leaching has been reported (McIntosh and Baglin 1992; Peters and Colo 1978). It was found that $85 \%$ zinc and $90 \%$ lead could be recovered by $\mathrm{NaOH}$ leaching within $2 \mathrm{~h}$ (Orhan 2005). Lenz and Martins (2007) successfully recovered $\mathrm{Zn}$ and $\mathrm{Pb}$ from steelmaking slag through precipitation after leaching (Lenz and Martins 2007).

Thermal (heating) treatment was reported to be an effective method for recovery $\mathrm{Zn}, \mathrm{Pb}$, and $\mathrm{Cr}$ due to the volatile property of these metals (Jalkanen et al. 2005). Rotary hearth furnace (RHF) is one of the most favorable technologies used in volatile metal recovery. The main principle of RHF is that the metal oxides such as zinc oxide and lead oxide will be reduced to corresponding elemental metals such as $\mathrm{Zn}$ and $\mathrm{Pb}$ under radiation heating in the presence of carbon (Ichikawa and Morishige 2002). The process could be simply described as Eq. (4). The volatile metals gasified will be separated from the slag and will go into exhausted gas. The vapor of the metals will turn to solid phase after cooling, and thus, the recovery is completed.

$$
\begin{aligned}
& \mathrm{Me}_{m} \mathrm{O}_{m}+n \mathrm{C} / \mathrm{CO} \longrightarrow m \mathrm{Me}+n \mathrm{CO} / \mathrm{CO}_{2} \\
& \mathrm{C}+\mathrm{O}_{2} \longrightarrow \mathrm{CO}_{2} \\
& \mathrm{C}+\mathrm{CO}_{2} \longrightarrow \mathrm{CO}
\end{aligned}
$$

where Me is metals.

In fact, the recovery of valuable metals from slag is also a way for iron and lime recycling since the residue 
will mainly contain iron and lime after metal recovery process. In addition, leaching could be an alternative of safe disposal of iron- and steelmaking slag besides thermal solidification which uses binders such as clay, fly ash, cullet and sand, cements, and anhydrite to stabilize the hazardous metals in the slag through hightemperature treatment (Tang et al. 2008; Wang et al. 2017).

\section{Outlook}

In fact, the slag application is mainly decided by its composition. As described in above sections, iron- and steelmaking slag has been widespreadly studied in construction and environmental treatment, and used to recovery valuable substances such as iron, lime, and heavy metals, as well. Application of the slag in these fields could extensively mitigate the increasing pressure for slag management. Among all, in present, use of the slag in road construction and building construction is the most effective and popular slag management strategy all over the world due to the mature technology and large quantity requirement in slag. However, high transportation cost, the risks on volume stability of the construction, and release of hazardous substances (heavy metals) have impacted the slag application. The use of the slag in environmental treatment including water treatment as adsorbent, filtration media, and neutralizing agent, in soil as soil conditioner and fertilizer, and in greenhouse capture and storage, are alternatives of slag management. However, different iron- and steelmaking processes make the property of generated slag varied, and thus, the application of the slag in environmental treatment is complicated. The recovery of useful substances from the slag is economical and promising method in slag management as iron and lime in large fractions in slag after recovery can be reused in iron- and steelmaking industry and the slag after heavy metals extraction can be safely disposed or used as soil conditioner or fertilizer.

Overall, to some extend the current management on iron- and steelmaking slag could solve the large amount slag disposal problem; however, there are still challenges. The following work is required for costeffective use and safe disposal of the slag:
1. Study on proper treatments for enhance volume stability of the slag in construction is highly demanded;

2. Long-term behavior of the toxic substances in slag using in construction should be evaluated, and proper measures should be taken to avoid the negative impacts of the slag on environment and human beings;

3. The cost balance should be evaluated on slag application in environmental treatment as well as on substance recovery from slag;

4. Slag application in environmental treatment has great potential as it simultaneously reduces slag burden to environment and benefits to environmental treatment;

5. Most of the applications of slag in environmental treatment are still in study stage (lab-scale); therefore, practical application of the slag should be investigated.

The production of slag is inevitable as by-product of iron- and steelmaking industry. As the increase of iron- and steel production, slag management becomes difficult due to the large amount generation. The promising management methods including utilization of iron- and steelmaking slag in construction and environmental treatment have been extensively reported; however, the concern on volume stability and the release of toxic metals have to be given special attention before application. Recovery of valuable substances from slag is another suitable way of the management. In fact, the current usage of the slag is still in the initial stage. Its application in environmental treatment has great potential, and great efforts are demanded in the field.

Acknowledgements Sincere thanks are due to the grant Major Project of National Water Pollution Control and Governance of Science and Technology (2017ZX07401001) and Shenzhen scientific research foundation for high-level talent (KQJSCX20180328165658476), and Shenzhen scientific fundamental research foundation (JCYJ20180306171843211) for their financial support.

\section{Compliance with ethical standards}

Conflict of interest The authors declare that they have no conflict of interest. 


\section{References}

Ahmaruzzaman, M. (2011). Industrial wastes as low-cost potential adsorbents for the treatment of wastewater laden with heavy metals. Advances in Colloid and Interface Science, 166(1), 36-59.

Alanyali, H., Col, M., Yilmaz, M., \& Karagoz, S. (2009). Concrete produced by steel-making slag (basic oxygen furnace) addition in portland cement. International Journal of Applied Ceramic Technology, 6, 736-748.

Ali, M. T., \& Shahram, S. H. (2007). Converter slag as a liming agent in the amelioration of acidic soils. International Journal of Agriculture \& Biology, 5, 715-720.

Apul, D., Gardner, K., \& Taylloreighmy, T. (2005). Simultaneous application of dissolution/precipitation and surface complexation/surface precipitation modeling to contaminant leaching. Environmental Science and Technology, 39, 5736-5741.

Aramouni, N. A. K., Touma, J. G., Tarboush, B. A., Zeaiter, J., \& Ahmad, M. N. (2018). Catalyst design for dry reforming of methane: Analysis review. Renewable and Sustainable Energy Reviews, 82(Part 3), 2570-2585.

Baciocchi, R., Costa, G., Polettini, A., \& Pomi, R. (2015). Effects of thin-film accelerated carbonation on steel slag leaching. Journal of Hazardous Materials, 286(Supplement C), 369-378.

Balczár, I., Korim, T., Hullár, H., Boros, A., \& Makó, É. (2017). Manufacture of air-cooled slag-based alkali-activated cements using mechanochemical activation. Construction and Building Materials, 137(Supplement C), 216-223.

Bao, W., Li, H., \& Zhang, Y. (2010). Selective leaching of steelmaking slag for indirect $\mathrm{CO}_{2}$ mineral sequestration. Industrial and Engineering Chemistry Research, 49, 2055-2063.

Barca, C., Gérente, C., Meyer, D., Chazarenc, F., \& Andrès, Y. (2012). Phosphate removal from synthetic and real wastewater using steel slags produced in Europe. Water Research, 46(7), 2376-2384.

Barca, C., Meyer, D., Liira, M., Drissen, P., Comeau, Y., Andrès, Y., et al. (2014). Steel slag filters to upgrade phosphorus removal in small wastewater treatment plants: Removal mechanisms and performance. Ecological Engineering, 68(Supplement C), 214-222.

Barca, C., Roche, N., Troesch, S., Andrès, Y., \& Chazarenc, F. (2018). Modelling hydrodynamics of horizontal flow steel slag filters designed to upgrade phosphorus removal in small wastewater treatment plants. Journal of Environmental Management, 206(Supplement C), 349-356.

Basu, S., Lahiri, A. K., \& Seetharaman, S. (2008). Activity of iron oxide in steelmaking slag. Metallurgical and Materials Transactions B, 39, 447-456.

Battsengel, A., Batnasan, A., Narankhuu, A., Haga, K., Watanabe, Y., \& Shibayama, A. (2018). Recovery of light and heavy rare earth elements from apatite ore using sulphuric acid leaching, solvent extraction and precipitation. Hydrometallurgy, 179, 100-109.

Beh, C. L., Chuah, L., Choong, T. S. Y., Kamarudzaman, M. Z. B., \& Abdan, K. (2010). Adsorption study of electric arc furnace slag for the removal of manganese from solution. American Journal of Applied Sciences, 7, 442-446.
Biskri, Y., Achoura, D., Chelghoum, N., \& Mouret, M. (2017). Mechanical and durability characteristics of high performance concrete containing steel slag and crystalized slag as aggregates. Construction and Building Materials, 150(Supplement C), 167-178.

Bodurtha, P., \& Brassard, P. (2000). Neutralization of acid by steel-making slags. Environmental Technology, 21, 1271-1281.

Burciaga-Díaz, O., \& Escalante-García, J. I. (2017). Comparative performance of alkali activated slag/metakaolin cement pastes exposed to high temperatures. Cement \& Concrete Composites, 84(Supplement C), 157-166.

Cantarino, M. V., de Carvalho Filho, C., \& Borges Mansur, M. (2012). Selective removal of zinc from basic oxygen furnace sludges. Hydrometallurgy, 111-112(Supplement C), 124-128.

Carvalho, S. Z., Vernilli, F., Almeida, B., Demarco, M., \& Silva, S. N. (2017). The recycling effect of BOF slag in the portland cement properties. Resources, Conservation and Recycling, 127(Supplement C), 216-220.

Chen, S.-H., Lin, D.-F., Luo, H.-L., \& Lin, Z.-Y. (2017). Application of reclaimed basic oxygen furnace slag asphalt pavement in road base aggregate. Construction and Building Materials, 157(Supplement C), 647-653.

Claveau-Mallet, D., Courcelles, B., Pasquier, P., \& Comeau, Y. (2017). Numerical simulations with the P-Hydroslag model to predict phosphorus removal by steel slag filters. Water Research, 126(Supplement C), 421-432.

Claveau-Mallet, D., Wallace, S., \& Comeau, Y. (2013). Removal of phosphorus, fluoride and metals from a gypsum mining leachate using steel slag filters. Water Research, 47(4), 1512-1520.

Coppola, L., Buoso, A., Coffetti, D., Kara, P., \& Lorenzi, S. (2016). Electric arc furnace granulated slag for sustainable concrete. Construction and Building Materials, 123(Supplement C), 115-119.

Curkovii, L., Cerjan-Stefanovii, S., \& Rastovean-Mioe, A. (2000). Batch $\mathrm{Pb}^{2+}$ and $\mathrm{Cu}^{2+}$ removal by electric furnace slag. Water Research, 35, 3436-3440.

Da'na, E., \& Awad, A. (2017). Regeneration of spent activated carbon obtained from home filtration system and applying it for heavy metals adsorption. Journal of Environmental Chemical Engineering, 5(4), 3091-3099.

Danilov, E. V. (2003). Modern technology for recycling steelmaking slags. Metallurgist, 47, 232-234.

Dieter, G., Karl, W., \& Konrad, M. (1988). Process and device for producing granulated slag sand from blast furnace slag. Application Number: 07/004475.

Dimitrova, S. V. (1996). Metal sorption on Blast-furnace slag. Water Research, 30, 228-232.

Dimitrova, S. V. (2002). Use of granular slag columns for lead removal. Water Research, 36, 4001-4008.

Duan, J., \& Su, B. (2014). Removal characteristics of Cd(II) from acidic aqueous solution by modified steel-making slag. Chemical Engineering Journal, 246(Supplement C), 160-167.

El-Naas, M. H., El Gamal, M., Hameedi, S., \& Mohamed, A.-M. O. (2015). $\mathrm{CO}_{2}$ sequestration using accelerated gas-solid carbonation of pre-treated EAF steel-making bag house dust. Journal of Environmental Management, 156(Supplement C), 218-224. 
Emery, J. (1992). Mineral aggregate conservation reuse and recycling. Report prepared by Geotechnical Engineering Limited for Aggregate and Petroleum Resources Section, Ontario Ministry of Natural Resources, Ontario, 1992.

Ferreira, V. J., Sáez-De-Guinoa Vilaplana, A., García-Armingol, T., Aranda-Usón, A., Lausín-González, C., LópezSabirón, A. M., et al. (2016). Evaluation of the steel slag incorporation as coarse aggregate for road construction: technical requirements and environmental impact assessment. Journal of Cleaner Production, 130(Supplement C), 175-186.

Fidalgo, B., Bermudez, J. M., Arenillas, A., \& Menendez, J. A. (2009). Steel-making slag as catalyst for dry reforming of $\mathrm{CH} 4$. In 1st Spanish national conference on advances in materials recycling and eco-energy, Madrid, November 12-13, 2009, S04-01.

Gahan, C. S., Cunha, M. L., \& Sandström, ̊̊. (2009). Comparative study on different steel slags as neutralising agent in bioleaching. Hydrometallurgy, 95(3), 190-197.

Gao, H., Song, Z., Zhang, W., Yang, X., Wang, X., \& Wang, D. (2017). Synthesis of highly effective absorbents with waste quenching blast furnace slag to remove methyl orange from aqueous solution. Journal of Environmental Sciences, 53(Supplement C), 68-77.

Geiseler, J. (1996). Use of steelworks slag in Europe. Waste Management, 16, 59-63.

Genç-Fuhrman, H., Mikkelsen, P. S., \& Ledin, A. (2007). Simultaneous removal of $\mathrm{As}, \mathrm{Cd}, \mathrm{Cr}, \mathrm{Cu}, \mathrm{Ni}$ and $\mathrm{Zn}$ from stormwater: Experimental comparison of 11 different sorbents. Water Research, 41(3), 591-602.

Ghouleh, Z., Guthrie, R. I. L., \& Shao, Y. (2017). Production of carbonate aggregates using steel slag and carbon dioxide for carbon-negative concrete. Journal of CO2 Utilization, 18(Supplement C), 125-138.

Goetz, E. R., \& Riefler, R. G. (2014). Performance of steel slag leach beds in acid mine drainage treatment. Chemical Engineering Journal, 240(Supplement C), 579-588.

Gomes, J. F. P., \& Pinto, C. G. (2006). Leaching of heavy metals from steelmaking slags. Revista De Metalurgia, 42, 409-416.

Gopinath, S., \& Mehra, A. (2016). Carbon sequestration during steel production: Modelling the dynamics of aqueous carbonation of steel slag.". Chemical Engineering Research and Design, 115(Part A), 173-181.

Han, C., Wang, Z., Yang, W., Wu, Q., Yang, H., \& Xue, X. (2016). Effects of $\mathrm{pH}$ on phosphorus removal capacities of basic oxygen furnace slag. Ecological Engineering, 89(Supplement C), 1-6.

Han, C., Wang, Z., Yang, H., \& Xue, X. (2015). Removal kinetics of phosphorus from synthetic wastewater using basic oxygen furnace slag. Journal of Environmental Sciences, 30(Supplement C), 21-29.

Hashim, M. A., Mukhopadhyay, S., Sahu, J. N., \& Sengupta, B. (2011). Remediation technologies for heavy metal contaminated groundwater. Journal of Environmental Management, 92(10), 2355-2388.

He, H., Tam, N. F. Y., Yao, A., Qiu, R., Li, W. C., \& Ye, Z. (2017). Growth and Cd uptake by rice (Oryza sativa) in acidic and Cd-contaminated paddy soils amended with steel slag. Chemosphere, 189(Supplement C), 247-254.
Heikal, M., Al-Duaij, O. K., \& Ibrahim, N. S. (2015). Microstructure of composite cements containing blastfurnace slag and silica nano-particles subjected to elevated thermally treatment temperature. Construction and Building Materials, 93(Supplement C), 1067-1077.

Heribeert, M., \& Kuehn, M. (2004). Iron and steel slags as sustainable construction resources and fertilizer. In SCANMET-2nd international conference on process development in iron and steel making, Sweden (pp. 347-358).

Hiroyuki, T., Koichi, T., \& Tatsuhito, T. (2005). Steelmaking slag: uses and trends of development of uses. Current Advances in Materials and Processes, 18, 1060-1072.

Hocheng, H., Su, C., \& Jadhav, U. U. (2014). Bioleaching of metals from steel slag by Acidithiobacillus thiooxidans culture supernatant. Chemosphere, 117(Supplement C), $652-657$.

Huijgen, W. J. J., \& Comans, R. N. J. (2003). Carbon dioxide sequestration by mineral carbonation, literature review. ECN School Fossiel: Netherlands, 1, 1-13.

Ichikawa, H., \& Morishige, H. (2002). Effective use of steelmaking dust and sludge by use of Rotary Hearth Furnace. Nippon Steel Technical Report No. 86 July 2002.

Jalkanen, H., Oghbasilasie, H., \& Raipala, K. (2005). Recycling of steelmaking dusts-the radust concept. Journal of Mining and Metallurgy, 41B, 1-16.

Jha, V. K., Kameshima, Y., Nakajima, A., \& Okada, K. (2004). Hazardous ions uptake behavior of thermally activated steel-making slag. Journal of Hazardous Materials, 114(1), 139-144.

Jha, V. K., Kameshima, Y., Nakajima, A., \& Okada, K. (2008). Utilization of steel-making slag for the uptake of ammonium and phosphate ions from aqueous solution. Journal of Hazardous Materials, 156(1), 156-162.

Jo, Y., Kim, J., Hwang, S., \& Lee, C. (2015). Anaerobic treatment of rice winery wastewater in an upflow filter packed with steel slag under different hydraulic loading conditions. Bioresource Technology, 193(Supplement C), 53-61.

Jukes, L. M. (2003). The volume stability of modern steel making slag. Mineral Processing and Extractive Metallurgy, 112, 177-197.

Kadirova, Z. C., Hojamberdiev, M., Bo, L., Hojiyev, R., \& Okada, K. (2015). Simultaneous removal of $\mathrm{NH}^{4+}$, $\mathrm{H}_{2} \mathrm{PO}^{4-}$ and $\mathrm{Ni}^{2+}$ from aqueous solution by thermally activated combinations of steel converter slag and spent alumina catalyst. Journal of Water Process Engineering, 8(Supplement C), 151-159.

Kalyoncu, R. S. (2000). Slag-iron and steel. U.S. Geological survey minerals yearbook 2000 (Vol. 71, pp. 1-3).

Kambole, C., Paige-Green, P., Kupolati, W. K., Ndambuki, J. M., \& Adeboje, A. O. (2017). Basic oxygen furnace slag for road pavements: A review of material characteristics and performance for effective utilisation in southern Africa. Construction and Building Materials, 148(Supplement C), 618-631.

Karnib, M., Kabbani, A., Holail, H., \& Olama, Z. (2014). Heavy metals removal using activated carbon, silica and silica activated carbon composite. Energy Procedia, 50(Supplement C), 113-120. 
Ke, X., Bernal, S. A., \& Provis, J. L. (2016). Controlling the reaction kinetics of sodium carbonate-activated slag cements using calcined layered double hydroxides. Cement and Concrete Research, 81(Supplement C), 24-37.

Kim, D.-H., Shin, M.-C., Choi, H.-D., Seo, C.-I., \& Baek, K. (2008). Removal mechanisms of copper using steel-making slag: adsorption and precipitation. Desalination, 223, 283-289.

Lan, Y.-P., Liu, Q.-C., Meng, F., Niu, D.-L., \& Zhao, H. (2017). Optimization of magnetic separation process for iron recovery from steel slag. Journal of Iron and Steel Research International, 24(2), 165-170.

Le, D.-H., Sheen, Y.-N., \& Bui, Q.-B. (2017). An assessment on volume stabilization of mortar with stainless steel slag sand. Construction and Building Materials, 155(Supplement C), 200-208.

Lenz, D. M., \& Martins, F. B. (2007). Lead and zinc selective precipitation from leach electric arc furnace dust solutions. Revista Materia, 12, 503-509.

Li, Y., \& Dai, W.-B. (2018). Modifying hot slag and converting it into value-added materials: A review. Journal of Cleaner Production, 175(Supplement C), 176-189.

Li, Q., Ding, H., Rahman, A., \& He, D. (2016). Evaluation of basic oxygen furnace (BOF) material into slag-based asphalt concrete to be used in railway substructure. Construction and Building Materials, 115(Supplement C), 593-601.

Li, W., Lang, L., Wang, D., Wu, Y., \& Li, F. (2018). Investigation on the dynamic shear modulus and damping ratio of steel slag sand mixtures. Construction and Building Materials, 162(Supplement C), 170-180.

Li, H., Li, Y., Gong, Z., \& Li, X. (2013). Performance study of vertical flow constructed wetlands for phosphorus removal with water quenched slag as a substrate. Ecological Engineering, 53(Supplement C), 39-45.

Lobato, N. C. C., Villegas, E. A., \& Mansur, M. B. (2015). Management of solid wastes from steelmaking and galvanizing processes: A brief review. Resources, Conservation and Recycling, 102(Supplement C), 49-57.

Lu, S.-G., Bai, S.-Q., \& Shan, H.-D. (2008). Mechanisms of phosphate removal from aqueous solution by blast furnace slag and steel furnace slag. Journal of Zhejiang University Science A, 9, 125-132.

Masindi, V., Osman, M. S., \& Abu-Mahfouz, A. M. (2017). Integrated treatment of acid mine drainage using BOF slag, lime/soda ash and reverse osmosis (RO): Implication for the production of drinking water. Desalination, 424(Supplement C), 45-52.

Masindi, V., Osman, M. S., Mbhele, R. N., \& Rikhotso, R. (2018). Fate of pollutants post treatment of acid mine drainage with basic oxygen furnace slag: Validation of experimental results with a geochemical model. Journal of Cleaner Production, 172(Supplement C), 2899-2909.

McIntosh, S. N., \& Baglin, E. G. (1992). Recovery of manganese from steel plant slag by carbamate leaching. Report of Investigation.

Mercado-Borrayo, B. M., Schouwenaars, R., Litter, M. I., Montoya-Bautista, C. V., \& Ramírez-Zamora, R. M. (2014). 5-Metallurgical slag as an efficient and economical adsorbent of arsenic. In S. Ahuja (Ed.), Water reclamation and sustainability (pp. 95-114). Boston: Elsevier.

Mihok, L., Demeter, P., Baricova, D., \& Seilerova, K. (2006). Utilization of ironmaking and steelmaking slags. Metalurgija, 45, 163-168.

Moodley, I., Sheridan, C. M., Kappelmeyer, U., \& Akcil, A. (2017). Environmentally sustainable acid mine drainage remediation: Research developments with a focus on waste/by-products. Minerals Engineering, 126, 207-220.

Murthy, I. N., \& Rao, J. B. (2016). Investigations on physical and chemical properties of high silica sand, $\mathrm{Fe}-\mathrm{Cr}$ slag and blast furnace slag for foundry applications. Procedia Environmental Sciences, 35(Supplement C), 583-596.

Negim, O., Eloifi, B., Mench, M., Bes, C., Gaste, H., MotelicaHeino, M., et al. (2010). Effect of basic slag addition on soil properties, growth and leaf mineral composition of beans in a Cu-contaminated soil. Journal Soil and Sediment Contamination, 19, 174-187.

Oh, C., Rhee, S., Oh, M., \& Park, J. (2012). Removal characteristics of $\mathrm{As}(\mathrm{III})$ and $\mathrm{As}(\mathrm{V})$ from acidic aqueous solution by steel making slag. Journal of Hazardous Materials, 213-214(Supplement C), 147-155.

Okada, K., Yamamoto, T., Kim, K.-H., Asaoka, S., Hayakawa, S., Takeda, K., et al. (2014). Removal of hydrogen sulfide with steelmaking slag by concurrent reactions of sulfide mineralization and oxidation. Ecological Engineering, 63(Supplement C), 122-126.

Orhan, G. (2005). Leaching and cementation of heavy metals from electric arc furnace dust in alkaline medium. $\mathrm{Hy}$ drometallurgy, 78(3-4), 236-245.

Ouda, A. S., \& Abdel-Gawwad, H. A. (2017). The effect of replacing sand by iron slag on physical, mechanical and radiological properties of cement mortar. HBRC Journal, 13(3), 255-261.

Pan, S.-Y., Adhikari, R., Chen, Y.-H., Li, P., \& Chiang, P.-C. (2016). Integrated and innovative steel slag utilization for iron reclamation, green material production and $\mathrm{CO}_{2}$ fixation via accelerated carbonation. Journal of Cleaner Production, 137(Supplement C), 617-631.

Pap, S., Šolević Knudsen, T., Radonić, J., Maletić, S., Igić, S. M., \& Turk Sekulić, M. (2017). Utilization of fruit processing industry waste as green activated carbon for the treatment of heavy metals and chlorophenols contaminated water. Journal of Cleaner Production, 162(Supplement C), 958-972.

Park, T., Ampunan, V., Maeng, S., \& Chung, E. (2017). Application of steel slag coated with sodium hydroxide to enhance precipitation-coagulation for phosphorus removal. Chemosphere, 167(Supplement C), 91-97.

Pasetto, M., Baliello, A., Giacomello, G., \& Pasquini, E. (2017). Sustainable solutions for road pavements: A multi-scale characterization of warm mix asphalts containing steel slags. Journal of Cleaner Production, 166(Supplement C), 835-843.

Peters, M. A., \& Colo, A. (1978). Process for recovering zinc from steel-making flue dust. United States Patent 4071357.

Piatak, N. M., Parsons, M. B., \& Seal, R. R. (2015). Characteristics and environmental aspects of slag: A review. Applied Geochemistry, 57(Supplement C), 236-266.

Qiu, H., Gu, H.-H., He, E.-K., Wang, S.-Z., \& Qiu, R.-L. (2012). Attenuation of metal bioavailability in acidic multi-metal 
contaminated soil treated with fly ash and steel slag. Pedosphere, 22(4), 544-553.

Rawlins, C. H. (2008). Geological sequestration of carbon dioxide by hydrous carbonate formation in steelmaking slag a dissertation. Doctoral thesis presented to the Faculty of the Graduate School of the Missouri University of Science and Technology, pp. 1-247.

Reddy, A. S., Pradhan, R. K., \& Chandra, S. (2006). Utilization of basic oxygen furnace (BOF) slag in the production of a hydraulic cement binder. International Journal of Mineral Processing, 79, 98-105.

Reis da Silva, J.-B., Gois de Carvalho, K.-M., Bicudo Filho, P.S., de Abreu, L.-D., \& Rossi, L.-A. (2007). Environmental risks analysis on LD steel making slag use for road pavement applications. Revue de Métallurgie, 11, 540-550.

Santamaría, A., Orbe, A., Losañez, M. M., Skaf, M., OrtegaLopez, V., \& González, J. J. (2017). Self-compacting concrete incorporating electric arc-furnace steelmaking slag as aggregate. Materials and Design, 115(Supplement C), 179-193.

Santos, R. M., Van Bouwel, J., Vandevelde, E., Mertens, G., Elsen, J., \& Van Gerven, T. (2013). Accelerated mineral carbonation of stainless steel slags for $\mathrm{CO}_{2}$ storage and waste valorization: Effect of process parameters on geochemical properties. International Journal of Greenhouse Gas Control, 17(Supplement C), 32-45.

Sarkar, C., Basu, J. K., \& Samanta, A. N. (2017). Removal of $\mathrm{Ni}^{2+}$ ion from waste water by geopolymeric adsorbent derived from LD slag. Journal of Water Process Engineering, 17(Supplement C), 237-244.

Senani, M., Ferhoune, N., \& Guettala, A. (2016). Substitution of the natural sand by crystallized slag of blast furnace in the composition of concrete. Alexandria Engineering Journal, 57, 851-857.

Shen, H., \& Forssberg, E. (2003). An overview of recovery of metals from slags. Waste Management, 23(10), 933-949.

Spooren, J., Kim, E., Horckmans, L., Broos, K., Nielsen, P., \& Quaghebeur, M. (2016). In-situ chromium and vanadium recovery of landfilled ferrochromium and stainless steel slags. Chemical Engineering Journal, 303(Supplement C), 359-368.

Sun, Y., Yao, M.-S., Zhang, J.-P., \& Yang, G. (2011). Indirect $\mathrm{CO}_{2}$ mineral sequestration by steelmaking slag with $\mathrm{NH}_{4} \mathrm{Cl}$ as leaching solution. Chemical Engineering Journal, 173(2), 437-445.

Sun, S., \& Yuan, Y. (1983). Study of steel slag cement. Silicates Industrials, 2, 31-34.

Takahashi, T., \& Yabuta, K. (2002). New applications for iron and steelmaking slag. NKK Technical Review, 87, 39-44.

Tang, M.-T., Peng, J., Peng, B., Yu, D., \& Tang, C.-B. (2008). Thermal solidification of stainless steelmaking dust. Transactions of the Nonferrous Metals Society of China, 18, 202-206.

Tsutsumi, T., Nishimoto, S., Kameshima, Y., \& Miyake, M. (2014). Hydrothermal preparation of tobermorite from blast furnace slag for $\mathrm{Cs}^{+}$and $\mathrm{Sr}^{2+}$ sorption. Journal of Hazardous Materials, 266(Supplement C), 174-181.

Turhan, B. (2006). Use of granulated blast-furnace slag in concrete as fine aggregate. ACI Materials Journal, 103, 203-208.
Ukwattage, N. L., Ranjith, P. G., \& Li, X. (2017). Steel-making slag for mineral sequestration of carbon dioxide by accelerated carbonation. Measurement, 97(Supplement C), $15-22$.

Velenturf, A. P. M., Archer, S. A., Gomes, H. I., Christgen, B., Lag-Brotons, A. J., \& Purnell, P. (2019). Circular economy and the matter of integrated resources. Science of the Total Environment, 689, 963-969.

Vijayaraghavan, J., Jude, A. B., \& Thivya, J. (2017). Effect of copper slag, iron slag and recycled concrete aggregate on the mechanical properties of concrete. Resources Policy, 53(Supplement C), 219-225.

Wang, G. C. (2016). 9-Usability criteria for slag use as a granular material. In G. C. Wang (Ed.), The utilization of slag in civil infrastructure construction (pp. 185-199). Cambridge: Woodhead Publishing.

Wang, X., \& Cai, Q.-S. (2006). Steel slag as an iron fertilizer for corn growth and soil improvement in a pot experiment. Pedosphere, 16(4), 519-524.

Wang, H., Ding, B., Liu, X.-Y., Zhu, X., He, X.-Y., \& Liao, Q. (2017). Solidification behaviors of a molten blast furnace slag droplet cooled by air. Applied Thermal Engineering, 127(Supplement C), 915-924.

Wang, P., Kara, S., \& Hauschild, M. Z. (2018). Role of manufacturing towards achieving circular economy: The steel case. CIRP Annals, 67(1), 21-24.

Wang, Y., \& Lin, D. (1983). The steel slag blended cement. Silicates Industrials, 6, 121-126.

Worldsteel Association (2016). Retrieved September 15, 2017 from http://www.worldsteel.org/statistics/crudesteelproduction.html.

Wu, Q., You, R., Clark, M., \& Yu, Y. (2014). Pb(II) removal from aqueous solution by a low-cost adsorbent dry desulfurization slag. Applied Surface Science, 314(Supplement C), 129-137.

Xiang, J., Huang, Q., Lv, X., \& Bai, C. (2018). Extraction of vanadium from converter slag by two-step sulfuric acid leaching process. Journal of Cleaner Production, 170(Supplement C), 1089-1101.

Xie, M., Leung, A. K., \& Ng, C. W. W. (2017). Mechanisms of hydrogen sulfide removal by ground granulated blast furnace slag amended soil. Chemosphere, 175(Supplement C), 425-430.

Xue, Y., Hou, H., \& Zhu, S. (2009). Competitive adsorption of copper(II), cadmium(II), lead(II) and zinc(II) onto basic oxygen furnace slag. Journal of Hazardous Materials, 162, 391-401.

Yildirim, I. Z., \& Prezzi, M. (2017). Experimental evaluation of EAF ladle steel slag as a geo-fill material: Mineralogical, physical \& mechanical properties. Construction and Building Materials, 154(Supplement C), 23-33.

Yilmaz, D., Lassabatere, L., Angulo-Jaramillo, R., Deneele, D., \& Legret, M. (2010). Hydrodynamic characterization of basic oxygen furnace slag through an adapted BEST method. Vadose Zone, 9, 107-116.

Yu, J., Liang, W., Wang, L., Li, F., Zou, Y., \& Wang, H. (2015). Phosphate removal from domestic wastewater using thermally modified steel slag. Journal of Environmental Sciences, 31(Supplement C), 81-88.

Yuan, B., Straub, C., Segers, S., Yu, Q. L., \& Brouwers, H. J. H. (2017). Sodium carbonate activated slag as cement 
replacement in autoclaved aerated concrete. Ceramics International, 43(8), 6039-6047.

Zahar, M. S. M., Kusin, F. M., \& Muhammad, S. N. (2015). Adsorption of manganese in aqueous solution by steel slag. Procedia Environmental Sciences, 30(Supplement C), 145-150.

Zhang, F.-S., \& Itoh, H. (2006). Photocatalytic oxidation and removal of arsenite from water using slag-iron oxide- $\mathrm{TiO}_{2}$ adsorbent. Chemosphere, 65(1), 125-131.

Zhou, W., Huang, Z., Sun, C., Zhao, H., \& Zhang, Y. (2016). Enhanced phosphorus removal from wastewater by growing deep-sea bacterium combined with basic oxygen furnace slag. Bioresource Technology, 214(Supplement C), 534-540.

Zuo, M., Renman, G., Gustafsson, J. P., \& Renman, A. (2015). Phosphorus removal performance and speciation in virgin and modified argon oxygen decarburisation slag designed for wastewater treatment. Water Research, 87(Supplement C), 271-281.

Publisher's Note Springer Nature remains neutral with regard to jurisdictional claims in published maps and institutional affiliations. 